\title{
AKTIVITAS ANTIOKSIDAN TEH DAUN KELOR (Moringa oliefera) -ROSELA (Hibiscus sabdariffa L) DENGAN VARIASI LAMA PENGERINGAN
}

\author{
Antioxidant Activity of Moringa Leaf (Moringa oleifera) - \\ Rosella (Hibiscus sabdariffa L) Tea With Drying Period Variation
}

\author{
Hangga Wahyudi, Akhmad Mustofa, Yannie Asrie Widanti \\ Fakultas Teknologi dan Industri Pangan Universitas Slamet Riyadi Surakarta, \\ Jl. Sumpah Pamuda 18 Joglo Kadipiro Surakarta 57136 \\ Email: hanggawahyudi14@gmail.com
}

\begin{abstract}
ABSTRAK
Moringa olifiera yang kita kenal dengan nama Kelor adalah salah satu tanaman yang bergizi, sejak dahulu dikenal oleh masyarakat Indonesia sebagai tanaman yang berkhasiat. Daun kelor dalam pembuatan teh sangat bermanfaat untuk kesehatan karena mengandung kandungan flavonoid sebagai antioksidan dan antiinflamasi. Tanaman kelor sudah dikenal luas di Indonesia, khususnya didaerah pedesaan, tetapi belum dimanfaatkan secara maksimal dalam kehidupan sehari-hari. Penelitian dilakukan dengan menggunakan Rancangan Acak Lengkap (RAL) faktorial yang terdiri dari 2 faktor. Faktor pertama dengan rasio daun kelor dan rosela (1:1, 2:1, 1:2) sedangkan faktor yang kedua lama pengeringan (6o, 80, 120 menit). Tujuan penelitian ini adalah untuk menghasilkan teh kering yang bersifat fungsional dan mengandung antioksidan tinggi serta disukai konsumen. Hasil penelitian menunjukan kombinasi perlakuan rasio daun kelor dan rosela 1:2 adalah yang paling optimal, selain karena aktivitas antioksidan yang tinggi dan agak disukai berdasarkan uji organoleptik. Pada perlakuan ini dihasilkan kadar abu 6,33\%, aktivitas antioksidan 64,59\%, fenol 2,21\%, pH 4,79, serta uji organoleptik terhadap kesukaan keseluruhan yaitu 2,87 (sedikit suka).
\end{abstract}

Kata kunci: Antioksidan, teh, kelor, rosela, pengeringan.

\begin{abstract}
Moringa olifiera which we know as kelor was one of plants that nutritious, since long time ago known by Indonesian people as beneficial plant. Moringa leaf in the making of tea was very useful for health because it contains of flavonoid as antioxidant and anti-inflamation. Moringa leaf has been already known widely in Indonesia, especially in village area, but not yet fully utilized in daily life.

Aim of this research was to produce functional dried tea consisted high antioxidant and liked by consumers. The research used Completely Randomized Design (RAL) factorial which consisted of two factors. The first factor was with kelor leaf and rosela ratio (1:1, 2:1, 1:2) the second factor was drying period (6o, 80, 120 minutes).

Results of this research showed that ratio of moringa leaf-rosella 1:2 was the most optimum treatment. This treatment had the high antioxidant activity and preferred by consumers. This treatment had 6,33\% of ash content, 64,59\% of antioxidant activity, 2,21\% of fenol, 4,79 of $\mathrm{pH}$, and 2,87 of preferred by consumers.
\end{abstract}

Keywords: Antioxidant, drying, tea, moringa, rosella. 


\section{PENDAHULUAN}

Di Indonesia pohon kelor banyak ditanam sebagai pagar hidup, ditanam di sepanjang ladang atau tepi sawah, berfungsi sebagai tanaman penghijau. Selain itu tanaman kelor juga dikenal sebagai tanaman obat berkhasiat dengan memanfaatkan seluruh bagian dari tanaman kelor mulai dari daun, kulit batang, biji, hingga akarnya (Simbolan et al., 2007). Moringa oleifera Lam yang kita kenal dengan nama Kelor adalah salah satu tanaman yang bergizi, sejak dahulu dikenal oleh masyarakat Indonesia sebagai tanaman yang berkhasiat (Krisnadi, dan Dudi, 2013). Daun kelor kering per $100 \mathrm{~g}$ mengandung air 7,5\%, kalori $205 \mathrm{~g}$, karbohidrat 38,2 g, protein 27,1 g, serat 19,2 g, lemak 2,3 g, kalsium $2003 \mathrm{mg}$, magnesium 368 $\mathrm{mg}$, fosfor $204 \mathrm{mg}$, tembaga o,6 mg, besi 28,2 $\mathrm{mg}$, sulfur $870 \mathrm{mg}$, potasium $1324 \mathrm{mg}$ (Haryadi dan Kholis, 2011). Daun kelor dalam pembuatan teh sangat bermanfaat untuk kesehatan karena mengandung kandungan flavonoid sebagai antioksidan dan antiinflamasi. Menurut Sashidhara et al. (2009) beberapa bagian dari kelor digunakan dalam pengobatan penyakit seperti rematik, kelumpuhan dan epilepsi, selain itu ekstrak daun, biji, dan akar dari pohon kelor telah dipelajari secara ekstensif dan analgesik. Kandungan fitokimia dalam daun kelor yaitu tanin, steroid dan triterpenoid, flavonoid, saponin, antraquinon, dan alkaloid. Flavonoid inilah yang mempengaruhi berbagai macam aktivitas biologi atau farmakologi, diantaranya antioksidan, antitumor, antiangiogenik, antialergik dan antiviral (Kasolo et al., 2010). Tanaman kelor sudah dikenal luas di Indonesia, khususnya di daerah pedesaan, tetapi belum dimanfaatkan secara maksimal dalam kehidupan sehari-hari. Menurut Wihastuti dan Andri (2007), daun kelor dapat menghambat aktifitas NF-K $\beta$ dan menurunkan ekspresi protein TNF $\alpha$ a dan ICAM-1 pada HUVECS yang terdapat LDL teroksidasi. Daun kelor mengandung dua jenis senyawa bioaktif yaitu quercetin dan kaempherol. Antioksidan quercetin termasuk flavonoid dapat mencegah kerusakan sel endotel pada binatang mencit yang terkena aterosklerosis dengan cara menghambat radikal bebas sehingga tidak terbentuk modifikasi LDL menjadi oxy-LDL (Wilcoz dan Subramanian, 1997). Oleh karena itu peneliti memiliki gagasan untuk mengolah daun kelor menjadi bahan utama pembuatan teh.

Rosela mengandung beberapa zat yang sangat penting bagi kesehatan. Tiap $100 \mathrm{~g}$ kelopak bunga segar mengandung 260-28o mg vitamin C. Selain itu, rosela juga mengandung vitamin $\mathrm{D}$, vitamin $\mathrm{B} 1, \mathrm{~B} 2$, niacin, riboflavin, betakaroten, zat besi, asam amino, polisakarida, omega 3, dan kalsium dalam jumlah yang cukup tinggi (486 mg/10o g). Rasa asam dalam bunga rosela merupakan perpaduan berbagai jenis asam, seperti asam askorbat (vitamin C), asam sitrat, dan asam malat yang juga bermanfaat bagi tubuh. Bahan aktif yang terdapat dalam rosela adalah grossy peptin, anthocyanin, gluside hibiscin, dan flavonoid yang bermanfaat mencegah kanker, mengendalikan tekanan darah, melancarkan peredaran darah, dan sebagainya. Manfaat bunga rosela dapat menyembuhkan gangguan pencernaan, merangsang defekasi, dan meningkatkan stamina (Maryani dan Kristiana, 2005). Menurut penelitian Hernani dan Nurdjanah (2009), tentang pengeringan tanaman obat, pengoven pada daun sambiloto dengan variasi suhu 40, 50 , dan $60^{\circ} \mathrm{C}$. Suhu pengeringan dengan oven akan mempengaruhi kualitas daun kering dan kandungan senyawa aktif daun tersebut. Diversifikasi terhadap suatu produk pangan perlu dilakukan untuk lebih meningkatkan potensi gizi dan senyawa aktif yang terkandung dalam produk pangan tersebut. Sehingga produk tersebut akan lebih mempunyai nilai tambah baik dari segi cita rasa maupun manfaatnya dalam menjaga kesehatan tubuh manusia.

\section{METODE PENELITIAN \\ Alat dan Bahan Penelitian}

Alat yang digunakan yaitu timbangan, cabinet dryer, pisau, sendok, baskom, loyang, dan peralatan analisis : Crush, timbangan, memmert, kompor listrik, $\mathrm{pH}$ meter, tabung reaksi, rak, spektometer, pipet volum. Bahan yang digunakan dalam penelitian yaitu daun kelor yang diperoleh dari daerah Karanganyar, dan rosela basah yang diperoleh dari Pasar Gede Surakarta. 


\section{Rancangan Percobaan}

Dalam penelitian ini rancangan percobaan yang digunakan adalah rancangan acak lengkap faktorial dengan faktor rasio daun kelor dan rosela (1:1, 2:1, 1:2) dan lama pengeringan dengan suhu $(60,80$, dan 120 menit). Jumlah perlakuan ada 9 perlakuan dan masing perlakuan diulang sebanyak 3 kali. Data yang diperoleh dianalisis dengan uji sidik ragam pada jenjang nyata o,05. Jika ada beda nyata dilanjutkan uji Tukey untuk mengetahui beda nyata antar perlakuan pada tingkat signifikasi $5 \%$.

\section{Pembuatan Teh Daun Kelor-Rosella segar (Adri dan Hersolistyorini, 2013)}

Daun kelor dan rosella segar dicuci, ditiriskan, kemudian lakukan pengeringan sesuai perlakuan 6o, 80, dan 120 menit, dan penimbangan, selanjutnya daun kelor-rosella bisa diseduh sebagai teh.

\section{Pembuatan Seduhan Teh Daun Kelor- Rosela (Sudaryat et al., 2015)}

Daun kelor dan rosela kering diambil sesuai perlakuan 1:1, 2:1, 1:2, dimasukkan dalam gelas dengan total kebutuhan $25 \mathrm{~g}$, didihkan air 1,250 ml murni sampai mendidih, berdasarkan kebutuhan analisis, dituangkan dalam gelas yang berisi daun kelor dan rosela, ditutup dan dibiarkan selama 5 menit kemudian disaring, teh daun kelor-rosela.

\section{Parameter Analisis}

Pada penelitian ini dilakukan analisis yang meliputi: aktivitas antioksidan (Yen dan Chen, 1995), kadar fenol dengan metode Chandler dan Dodds yang dimodifikasi (Shetty et al, 1995), kadar abu dengan metode thermogravimetri (Sudarmadji et al., 1997), analisis $\mathrm{pH}$ dengan $\mathrm{pH}$ meter (Apriyantono, 1989), dan uji organoleptik (Kartika et al, 1998).

\section{HASIL DAN PEMBAHASAN Kadar Abu Teh Daun Kelor-Rosela}

Kadar abu paling tinggi pada perlakuan rasio daun kelor terhadap rosela 2:1 dan lama pengeringan 60 menit yaitu $8,90 \%$ sedangkan kadar abu terendah adalah 6,33\% dengan perlakuan rasio daun kelor terhadap rosela 1:2 dan lama pengeringan 120 menit. Kadar abu teh daun kelor-rosela cenderung meningkat seiring dengan bertambahnya konsentrasi daun kelorrosela dan lama pengeringan yang dilakukan. Kadar abu daun kelor kering dalam $100 \mathrm{~g}$ bahan terdapat 7,95\% (Aminah et al., 2015) sedangkan kadar abu bunga rosela kering 6,9\% (Winarti et al., 2015). Semakin lama pengeringan, maka semakin rendah kadar abu yang dihasilkan. Hal ini disebabkan daun kelor memiliki kandungan mineral yang tinggi antara lain meliputi kalsium, kalium, zat besi, dan fosfor, sehingga semakin banyak kandungan dalam daun kelor yang akan terdenaturasi, misalnya protein dan mineral. Kandungan mineral juga dipengaruhi oleh jenis tanah yang digunakan sebagai media tumbuh, bila tanah tersebut mengandung mineral yang cukup tinggi, maka kandungan mineral akan semakin meningkat (Dwi, 2015).

\section{Aktivitas Antioksidan DPPH}

Aktivitas antioksidan tertinggi yaitu pada perlakuan rasio konsentrasi daun kelor dan rosela 1:2 dan lama pengeringan 120 menit yaitu sebesar $64,59 \%$ sedangkan aktivitas antioksidan terendah pada perlakuan rasio daun kelor dan rosela 2:1 dan lama pengeringan 8 o menit yaitu sebesar $54,77 \%$. Semakin tinggi konsentrasi rosela yang ditambahkan maka aktivitas antioksidan semakin meningkat. Hal ini disebabkan rosela mengandung banyak sekali antioksidan. Sehingga semakin tinggi penambahan rosela maka kandungan antioksidan pada teh daun kelor dan rosela semakin meningkat. Bunga rosela kering memiliki aktivitas antioksidan sebesar 99,05\% (Winarti et al., 2015) sedangkan aktivitas antioksidan daun kelor sebesar 81,5\% (Sari, 2015). Semakin lama pengeringan pada suhu $60^{\circ} \mathrm{C}$ maka aktivitas antioksidan semakin meningkat. Hal ini disebabkan aktivitas antioksidan dengan pengeringan 120 menit optimal menghasilkan aktivitas antioksidan paling tinggi dibandingkan dengan pengeringan 60 menit dan 80 menit padahal menggunakan suhu yang sama, yaitu $60^{\circ} \mathrm{C}$. Aktivitas antioksidan yang tertinggi yaitu lama pengeringan 120 menit dengan 
suhu $60^{\circ} \mathrm{C}$ disebabkan daun kelor dan rosela memiliki kandungan nutrisi serta senyawasenyawa antioksidan yang berupa asam fenolik, selenium, karotenoid, flavonoid, glutasion, koenzim Q10, melatonin dan likopen, senyawa tersebut tahan akan panas sehingga pada daun kelor dengan lama pengeringan 120 menit yang optimal menghasilkan aktivitas antioksidan menjadi tinggi (Rofiah, 2015) dan lama pengeringan dapat meningkatkan jumlah zat aktif dalam daun teh tersebut seperti asam fenolik, selenium, flavonoid, dan antosianin (Winarno, 1989). Menurut penelitian Ana (2011), suhu yang digunakan dalam pengeringan daun kelor adalah 50, 6o, dan $70^{\circ} \mathrm{C}$ dengan waktu 100, 160 dan 180 menit. Suhu yang terbaik dalam pembentukan flavonoid yang dapat membentuk antioksidan yang optimal yaitu dengan perlakuan suhu $60^{\circ} \mathrm{C}$ dan lama pengeringan 160 menit.

\section{Total Fenol Teh Daun Kelor-Rosela}

Kandungan fenol tertinggi yaitu pada perlakuan rasio konsentrasi daun kelor dan rosela 1:2 dan lama pengeringan 120 menit yaitu sebesar 2,21\% sedangkan kandungan fenol terendah pada perlakuan rasio daun kelor dan rosela 2:1 dan lama pengeringan 6o menit yaitu sebesar $1,74 \%$. Total fenol cenderung semakin meningkat seiring dengan bertambahnya rasio rosela dan lama pengeringan. Hal ini disebabkan karena rosela mengandung polifenol yang tinggi. Kandungan fenol rosela kering sebesar 22,01\% (Winarti et al., 2015) sedangkan kandungan fenol daun kelor kering sebesar 1,6\% (Aminah et al., 2015). Kandungan fenol tertinggi yaitu pada perlakuan rasio konsentrasi daun kelor dan rosela 1:2 dan lama pengeringan 120 menit, hal ini disebabkan senyawa senyawa antioksidan yang berupa asam fenolik tersebut tahan terhadap panas (Rofiah, 2015), asam fenolik tersebut bisa aktif pada suhu sekitar 50, 6o, dan $70^{\circ} \mathrm{C}$ dengan waktu 100, 160 dan 180 menit. Sehingga jika pengeringan dengan suhu $60^{\circ} \mathrm{C}$ selama 120 menit adalah suhu optimal untuk mengaktifkan senyawa fenol tersebut.

\section{Derajat Keasaman (pH) Teh daun Kelor- Rosela}

$\mathrm{pH}$ tertinggi pada teh daun kelor-rosela yaitu 4,86 diperoleh dari perlakuan rasio daun kelor-rosela 1:1 dan lama pengeringan 120 menit. Sedangkan $\mathrm{pH}$ terendah yaitu 4,65 diperoleh dari perlakuan rasio daun kelor-rosela 1:2 dan lama pengeringan 60 menit. Semakin tinggi penambahan bunga rosela maka $\mathrm{pH}$ tersebut semakin rendah sehingga menjadi asam. Bunga rosela memiliki pH yaitu 3,46 (Ali et al., 2013) sedangkan daun kelor memiliki $\mathrm{pH}$ sebesar 4,6 (Diantoro et al., 2015). Derajat keasaman teh tersebut dipengaruhi oleh faktor asam pada rosela dan daun kelor. Faktor asam tersebut berasal dari kandungan vitamin $C$ pada daun rosela. Vitamin $C$ akan berkurang jika pengeringan semakin lama dilakukan sehingga derajat keasamannya semakin tinggi dan rasa teh daun kelor-rosela tidak asam sehingga pengeringan dengan 120 menit dapat membuat pH semakin besar. Faktor yang mempengaruhi $\mathrm{pH}$ adalah penggunaan asam askorbat pada proses maserasi dalam pembuatan ekstrak (Andari et al., 2015). Jika pH tinggi maka asam tersebut semakin rendah sedangkan jika $\mathrm{pH}$ rendah maka asam semakin tinggi.

\section{Uji Organoleptik Terhadap Teh Daun Kelor-Rosela}

Uji organoleptik sangat penting dilakukan karena digunakan untuk mengetahui tingkat penerimaan konsumen terhadap produk yang dihasilkan. Penilaian secara organoleptik merupakan cara penilaian dengan indera. Menurut Kartika et al (1988), karakteristik pengujian organoleptik yaitu penguji cenderung melakukan penilaian berdasarkan kesukaan penguji, tanpa berlatih sebelumnya, pengujian dilakukan di tempat terbuka sehingga diskusi antar penguji mungkin terjadi. Menurut Winarno (1989), seringkali suatu produk makanan mempunyai komposisi gizi yang baik, namun tidak diterima oleh konsumen karena mempunyai sifat organoleptik yang menyimpang. 
Pengujian organoleptik pada penelitian ini meliputi warna, flavor, rasa, dan kesukaan keseluruhan oleh panelis terhadap produk teh daun kelor-rosela yang dibuat.

\section{Warna Teh Daun Kelor-Rosela}

Warna teh daun kelor-rosela yang paing merah yaitu $(3,13)$ diperoleh dari perlakuan daun kelor-rosela 1:2, semakin meningkat berat rasio rosela, maka warna teh daun kelor-rosela akan semakin kemerahan. Hal ini disebabkan antosianin pada rosela memberikan warna merah pada teh, dengan demikian peningkatan kadar rosela akan meningkatkan warna merah pada teh. Semakin lama pengeringan maka warna teh semakin merah, hal ini disebabkan kandungan antosianin pada rosela yang memberikan warna merah. Enzim yang mempengaruhi perubahan warna antosianin adalah enzim glikosidase dan fenolase. Enzim glikosidase akan menghidrolisis ikatan glikosida menghasilkan gugus gula dan aglikon. Enzim tersebut bisa aktif dan memberikan warna merah pada suhu $70^{\circ} \mathrm{C}$ dengan lama pengeringan 20 jam (Winarti et al., 2015).

\section{Flavor Khas Kelor dan Rosela}

Semakin meningkat berat rosela yang digunakan maka flavor rosela dari teh daun kelor-rosela semakin terasa meskipun tidak signifikan. Hasil penelitian menunjukkan bahwa perlakuan rasio daun kelor dan rosela 1:2 menghasilkan teh daun kelor-rosela dengan flavor kelor dan rosela terasa $(3,07)$. Pada perlakuan rasio daun kelor dan rosela 1:1 menghasilkan teh daun kelor-rosela dengan flavor kelor dan rosela sedikit terasa $(2,40)$. Semakin lama pengeringan maka flavor kelorrosela akan semakin terasa karena flavor kelor-rosela dipengaruhi oleh kandungan senyawa antioksidan seperti tanin, saponin, dan flavonoid. Senyawa antoksidan tersebut bisa aktif pada suhu sekitar 50,6o, dan $70^{\circ} \mathrm{C}$ dengan waktu 100, 160, dan 180 menit (Rofiah, 2015) sehingga $60^{\circ} \mathrm{C}$ dalam waktu 120 menit merupakan suhu optimum.

\section{Rasa Asam Teh Daun Kelor-Rosela}

Semakin lama pengeringan maka $\mathrm{pH}$ semakin tinggi sedangkan jika pengeringan tidak terlalu lama maka $\mathrm{pH}$ semakin rendah. Kandungan vitamin $C$ pada rosela mempengaruhi rasa asam pada teh daun kelor-rosela. Semakin tinggi $\mathrm{pH}$ maka rasa tidak terlalu asam sedangkan semakin rendah $\mathrm{pH}$ rasa semakin asam. Dalam penelitian ini teh yang paling asam yaitu teh yang memiliki $\mathrm{pH}$ yang rendah dengan lama pengeringan 6o menit pada rasio 1:2. Seharusnya jika rasio rosela semakin tinggi maka rasa semakin asam tetapi hal ini berbeda rasio kelor dan rosela dengan perbandingan 1:2 rasa semakin asam. Hal ini disebabkan perbedaan sensori pada panelis yang merasakan rasa asam pada teh kelor-rosela.

\section{Kesukaan Keseluruhan}

Semakin sedikit berat rosela yang digunakan maka tingkat kesukaan keseluruhan panelis terhadap teh daun kelor-rosela cenderung semakin tidak suka karena rasa asam pada rosela tidak terasa dan rasa sepat atau pahit daun kelor lebih terasa. Tetapi pada perlakuan lama pengeringan, semakin lama waktu pengeringan maka tingkat kesukaan panelis terhadap teh daun kelor-rosela cenderung semakin suka. Berdasarkan hasil uji organoleptik teh yang paling disukai $(3,00)$ adalah teh dengan perlakuan rasio daun kelor dan rosela sebesar 2:1 dan lama pengeringan selama 120 menit. Hal ini disebabkan karena teh yang dihasilkan pada perlakuan tersebut memiliki warna yang menarik yaitu merah, flavor khas rosela dan memiliki rasa asam meskipun tidak signifikan karena berbeda tidak nyata. Menurut Winarno (1989), selain komponen-komponen cita rasa (bau, rasa, dan rangsangan mulut) komponen yang sangat penting adalah timbulnya perasaan seseorang setelah memakan. Penilaian tingkat

kesukaan secara numerik sangat dipengaruhi oleh panelis.

\section{Rangkuman Hasil Analisis Kimiawi dan Organoleptik}

Berdasarkan SNI 3836:2013, kadar abu 
maksimal 8\%. Hasil analisis kimia menunjukkan kadar abu seluruh teh daun kelor-rosela telah memenuhi standar yang telah ditetapkan oleh SNI 3836:2013. Sesuai dengan tujuan dari penelitian ini yaitu mendapatkan teh daun kelor-rosela yang tinggi antioksidan dan disukai oleh konsumen serta memenuhi persyaratan teh yang telah ditetapkan oleh Badan Standarisasi Nasional Indonesia pada tahun 2013, maka perlakuan optimal diperoleh pada rasio daun kelor dan rosela sebanyak 1:2 serta lama pengeringan 120 menit. Pada perlakuan ini dihasilkan kadar abu 6,33\% (di bawah 8\%), total fenol 2,21\%, aktivitas antioksidan 64,59\%, pH 4,79 serta uji organoleptik terhadap kesukaan keseluruhan yaitu 2,87 (sedikit suka).

\section{KESIMPULAN}

Konsentrasi masing-masing perlakuan berpengaruh terhadap aktivitas antioksidan teh kering, semakin tinggi konsentrasi bahan maka aktivitas antioksidan semakin meningkat. Aktivitas antioksidan tertinggi yaitu pada perlakuan rasio konsentrasi daun kelor dan rosela 1:2 dan lama pengeringan 120 menit yaitu sebesar $64,5 \%$. Teh yang paling disukai $(2,87)$ adalah teh dengan perlakuan rasio daun kelor dan rosela sebesar 1:2 dan lama pengeringan selama 120 menit.

\section{DAFTAR PUSTAKA}

Adri, D., dan Hersolistyorini, W. 2013. Aktivitas Antioksidan dan Sifat Organoleptik Teh Daun Kelor. Berdasarkan Variasi Lama Pengeringan. Jurnal Pangan dan Gizi (4): 2-7.

Ali, F., Ferawati, Risma A., 2013. Ekstraksi Zat Warna dari Kelopak Bunga Rosela (Study pengaruh Konsentrasi Asam Asetat dan Asam Sitrat). Jurnal Teknik Kimia (19): 26-33.

Aminah S, Tezar R, Mufihani Y., 2015. Kandungan Nutrisi dan Sifat Fungsional Tanaman Kelor. Buletin Pertanian Perkotaan Jakarta: Balai Pengkaji Teknologi Pertanian.

Ana, T.S., 2011. Pengaruh Suhu dan Lama Pengeringan terhadap Kadar Vitamin A dan Vitamin C, serta Aktivitas
Antioksidan Teh Daun Kelor (Moringa oleifera Lam). Skripsi. Jawa Timur: Universitas Pembangunan Nasional. Andari, P., Bina, N.S., Ella, N., 2015. Penetan Aktifitas Antioksidan dan Nilai SPF Formula Losion Ekstrak Kelopak Bunga Rosela. E-Jouernal. Bogor: Universitas Pakuan.

Apriyantono, A., 1989. Petunjuk Laboratorium Analisis Pangan. Bogor: PAU Pangan dan Gizi Institut Pertanian Bogor.

Diantoro, A., Muzaki, R., Ratna, B., Hapsari, T.P., 2015. Pengaruh Penambahan Ekstrak Daun Kelor (Moringa oleifera L.) terhadap Kualitas Yoghurt. Jurnal Teknologi Pangan (6): 59-66.

Dwi, E.K., 2015. Pengaruh Suhu dan Lama Pengeringan terhadap Karakteristi Teh Herbal Daun Katuk. Jurnal Tugas Ahkir. Bandung: Universitas Pasundan

Haryadi dan Kholis, N., 2011. Kelor Herbal Multikhasiat. Solo: Delta Media

Hernani dan Nurdjanah, R., 2009. Aspek Pengeringan dalam Mempertahankan Kandungan Metabolit Sekunder pada Tanaman Obat. Jurnal Perkembangan Teknologi Tro (21): 33-39.

Kartika, B., P. Hastuti, dan W. Supartono, 1988. Pedoman Uji Inderawi Bahan Pangan. Yogyakarta: PAU Pangan dan Gizi Universitas Gadjah Mada.

Kasolo, J, N., Bimeya, GS., Ojok, L., Ochieng, J., Okwal-okeng, J, W. 2010. Ms Analysis and In Vitro Screening of Four Species of Mucuna. Asian Journal of Pharmaceutical and Clinical Research (5): 239-243.

Krisnadi, dan Dudi A., 2013. e-book Kelor Super Nutrisi. Blora: Kelorina.com

Maryani, H dan Kristiana, L., 2005. Khasiat dan Manfaat Bunga Rosela. Jakarta: Agromedia Pustaka.

Rofiah, D., 2015. Aktivitas Antioksidan dan Sifat Organoleptik Teh Daun Kelor Dengan Variasi Lama Pengeringan dan Penambahan Jahe Serta Lengkuas sebagai Perasa Alami. Skripsi. Surakarta: UniversitasMuhammadiyahSurakarta Sari, M.A., 2015. Aktivitas Antioksida Teh Daun Alpukat (Persea americana Mill) dengan 
Variasi Teknik dan Lama Pengeringan. Skripsi. Surakarta: Universitas Muhammadiyah Surakarta.

Sashidhara, K, V, J, N., Rosaiah, E., Tyagi, R., Shukla, R., Raghubir, SM., Rajendrn. 2009. Rare Dipeptide and Urea Derivaties from Roots of Moringa oliefera as Potential aAnti-inflammatory and Antinociceptive Agents, European Journal of Medicinal Chemistry (44): 432-436.

Shetty, K, Curtis, O.F., Levin, RE., Witkowsky, R. dan Ang, W. 1995. Prevention of Vitrification Associated with in Vitro Shooot Culture of Oregano (Origanum vulgare) by Pseudomanas spp. J. Plant Physiol. (147): 447-451

Simbolan, J. M., Sitorus, M., dan Katharina, N. 2007. Cegah Malnutrisi dengan Kelor. Kanisius: Yogyakarta.

Standar Nasional Indonesia, 2013. SNI 3836:2013: Teh Kering dalam kemasan. Badan Standarisasi Nasional. Jakarta

Sudarmadji, S., B. Haryono, dan Suhardi, 1997. Prosedur Analisa Bahan Makanan dan Pertanian. Yogyakarta: Liberty.
Sudaryat, Y., M. Kusmiati., C, R. Pelangi., A. Rustamsyah., dan Dadan. 2015. Aktivitas Antioksidan Seduhan Sepuluh Jenis Mutu Teh Hitam Indonesia. Jurnal Penelitian Teh dan Kina (18): 95-100.

Wihastuti dan Andri T., 2007. Efek Ekstrak Kelor Daun Kelor (Moringa oleifera) dalam Menghambat Aktivitas NfkB, Ekspresi TNF-a dan ICAm-1 pada HUVECS yang Dipapar LDL Teroksidasi. Jurnal Kardiologi Indonesia. Malang: Universitas Brawijaya (28): 181-188

Wilcoz, J. dan Subramanian, 1997. Expression of Multiple Isoforms of Nitric Oxide Synthase in Normal and Atherosclorotic Vessel. Journal Arteroscler Thormb Vasc Biology (17): 2479-2488.

Winarno, F.G., 1989. Kimia Pangan dan Gizi. Jakarta: Gramedia Pusaka Utama

Winarti, S., Sudaryanti., dan Dina, S.U., 2015. Karakteristik Dan Aktivitas Rosela Kering. Jurnal Rekapangan (9): 17-24

Yen, G. O. dan Chen, H. Y., 1995. Antioxidant Activity of Various Tea Extract in Relation to their Antimutagenicity. Journal AgriculturalFoodChemistry (43):27-32. 